Piotr Zamojski

Uniwersytet Gdański

E-MAIL: pedpz@ug.edu.pl

\title{
Pedagogika skupiona na rzeczy - wprowadzenie do idei
}

\section{STRESZCZENIE}

Artykuł jest poświęcony idei pedagogiki skupionej na rzeczy, która zostaje odróżniona od innych form centryzmu pedagogicznego: programocentryczności, nauczycielocentryczności i pajdocentryzmu. Analiza argumentów krytycznych wobec tych rodzajów skoncentrowania pedagogiki prowadzi do znanego problemu uwiądu wyobraźni ideologicznej. Idea pedagogiki skupionej na rzeczach jest analizowana jako propozycja wykroczenia poza ten stan. Badane są cztery fundamentalne założenia tej perspektywy: 1) istnieje jeden, wspólny świat; 2) rzecz jest pierwotna wobec przedmiotu; 3) rzeczy nie można używać, a jedynie można ją studiować; 4) istnieje edukacyjna równość, której miarą jest rzecz.

SŁoWA KLUCZOWE: Arendt, pedagogika po-krytyczna, pedagogika skupiona na rzeczy, studiowanie, rzecz

$\mathrm{W}$ niniejszym artykule zamierzam wstępnie zarysować ideę pedagogiki skupionej na rzeczy (thing-centred pedagogy), która wyrasta z po-krytycznej perspektywy myślenia o edukacji (zob. Hodgson i in., 2017, 2018). Po wstępnej uwadze dotyczącej rozumienia idei skoncentrowania pedagogiki dokonam przeglądu dotychczasowych sposobów skupiania pedagogiki wokół jednego z wymiarów sytuacji edukacyjnej (programu, nauczyciela i ucznia). W odniesieniu do tak wyodrębnionego podziału zostanie wprowadzona idea pedagogiki skupionej na rzeczy, której bardziej szczegółowa analiza będzie wymagać odniesienia do filozofii Hannah Arendt, Martina Heideggera, Giorgio Agambena oraz Jacques’a Rancière’a.

$\mathrm{Na}$ wstępie istotne są dwa zastrzeżenia. Po pierwsze, pedagogika skupiona na rzeczy wyłania się dziś przede wszystkim w obrębie anglojęzycznego świata teorii edukacji (jako thing-centred pedagogy) - stąd w niniejszym artykule anglojęzyczne terminy, stanowiące dla tej nowej koncepcji zasadnicze punkty odniesienia. Nie zawsze ich polskie odpowiedniki są w rodzimej pedagogice dobrze zakorzenione (np. curriculum-centred pedagogy), a jeśli są w codziennym użytku, to często - jak to jest na przykład w przypadku pajdocentry- 
zmu i student-centred pedagogy - ich zakresy znaczeniowe nie pokrywają się całkowicie. Jest to powód, dla którego będę się systematycznie odwoływał również do pojęć anglojęzycznych. Po drugie, anglojęzyczne zakorzenienie pedagogiki skupionej na rzeczy powoduje, że w niniejszym tekście nieco inaczej niż w polskiej tradycji rozumiane są podstawowe pojęcia pedagogiczne. Podczas gdy pedagogika w Polsce należy do niemieckojęzycznego kręgu ukształtowanego przez ideę Pädagogik, Anglosasi używają słowa pedagogy wyłącznie wodniesieniu do edukacji jako praktyki międzygeneracyjnego spotkania poza sferami publiczną i prywatną, w miejscu specjalnie zaaranżowanym do tego celu - wyłączając poza ten obszar wychowanie, które należy do sfery prywatnej (zob. Arendt, 2011; Vlieghe, 2016). Pomimo odwoływania się do pojęcia pedagogiki, nie będę zatem w niniejszym artykule odnosił się do kwestii wychowania. W tym sensie, zgodnie z polską tradycją nazewnictwa pedagogicznego, bardziej precyzyjną nazwą nurtu, o którym tutaj piszę mogłaby być „teoria kształcenia skupiona na rzeczach”. Zdecydowałem się jednak zachować oryginalną, anglojęzyczną formułę, nie tylko w trosce o spójność językową, ale przede wszystkim dlatego, że w sensie merytorycznym pedagogika skupiona na rzeczy wykracza poza dominujące w Polsce rozumienie kształcenia jako (trans)formacji intelektualnej czy poznawczej sfery funkcjonowania człowieka (por. Okoń, 1998). Zgodnie z zapowiedzią rozpoczynam od istotnej dla dalszego wywodu uwagi o koncentrowaniu teorii pedagogicznej.

\section{Poza krytykę opozycji 'centrum-peryferia'}

Niewątpliwie jednym z kluczowych osiągnięć humanistyki zachodniej $\mathrm{XX}$ wieku była krytyka opozycji centrum-peryferia, dokonana przez różne nurty myślowe nawiązujące do post-strukturalizmu. Źródłowe dla tego dokonania były badania Jacques’a Derridy (1999, 2002, 2004), wykazujące, że struktura języka jest zbudowana $\mathrm{z}$ binarnych opozycji, które są zróżnicowane ze względu na swoje normatywne znaczenie. Pierwszy z członów tych opozycji jest zawsze waloryzowany dodatnio i przez to uprzywilejowany, podczas gdy drugi z nich jest waloryzowany ujemnie ${ }^{1}$. Derrida wskazuje, że dyskurs

1 Opozycje te nie mają jednak charakteru całkowicie porządkującego strukturę języka i w tym sensie język nie ma arche, tzn. nie jest ugruntowany, ale stanowi wiecznie rozpleniającą się i różnicującą się strukturę. Problem, na który zwracał uwagę Derrida polega na tym, że język - który jako struktura zapośredniczająca ludzkie doświadczenie kształtuje ludzkie praktyki społeczne i stanowi podstawę konstrukcji społecznych instytucji - ma tendencję do zacierania śladów własnej przygodności i prezentowania tych struktur (a z nimi także praktyk i instytucji społecznych) jako zestalonych, naturalnych i ostatecznych. Strategia dekonstrukcji, która polega na ujawnianiu przygodności struktury języka 
ma zatem tendencję do osadzania się wokół jakiegoś centrum, które traktuje się jak normatywną miarę dla wszystkiego co inne, spychając w ten sposób to, co inne - jako to, co gorsze - na margines. Jak dowodzą badania prowadzone w nurcie post-kolonializmu, jedną z podstawowych opozycji kulturowego i politycznego funkcjonowania świata Zachodu jest ta pomiędzy centrum i peryferiami (zob. Said, 1991; Bhabha, 2010). To właśnie myślenie w kategoriach 'centrum-peryferia' odpowiada za praktyki deprecjonowania, marginalizowania, a w końcu także wykluczania i eksterminacji inności (Young, 2004). Krytyka eurocentryzmu, etnocentryzmu, a także logocentryzmu i fallogocentryzmu wraz z postulatami celebracji różnic i odpowiedzialności wobec Innego (por. Lévinas, 200o) zdaje się zatem wyznaczać zdecydowanie negatywny stosunek do myślenia w kategoriach centrum i peryferii.

Krytykę tę w polskiej pedagogice przyswajano w latach 9o. XX wieku (zob. np. Szkudlarek, 1993, 1995a, 1995b, 1997), ale jeszcze we wcześniejszym okresie badacze edukacji krytycznie posługiwali się opozycją „pedagogów głównego nurtu” i „pedagogów z marginesu” (zob. Kwaśnica, 1991). Niezależnie od tego, należy uznać, że krytyka opozycji 'centrum-peryferia' stanowi jeden z zasadniczych elementów odnowienia pedagogiki w Polsce po 1989 roku przez szeroko rozumiany dyskurs krytyczny.

Tym bardziej może dziwić, że pedagodzy ciągle afirmują różne nurty myślowe, które explicite mają centrystyczny charakter. Mamy zatem do czynienia z pedagogiką pajdocentryczną, czy skoncentrowaną na nauczycielu albo na programie kształcenia ${ }^{2}$. Co więcej, w niniejszym artykule staram się również przekonywać do centrystycznego w gruncie rzeczy stanowiska pedagogiki skupionej na rzeczy. Czy oznacza to zatem, że post-strukturalną krytykę opozycji 'centrum-peryferia' należy porzucić albo w jakiś sposób unieważnić? Wydaje się, że nie jest to ani potrzebne, ani wskazane - nie mówiąc już o skali trudności takiego zadania.

Postaram się raczej pokazać, że zasadnicza 'centryczność' pedagogiki istotowo nie ma charakteru wykluczającego i dlatego nie wikła się w krytykę opozycji 'centrum-peryferia'. Posłużę się tutaj kategorią wprowadzoną przez niemieckiego dydaktyka Martina Wagenscheina (2010), który twierdził, że kluczowym zadaniem nauczyciela/lki - niezależnie od tego, w jakim punkcie

(przez wskazywanie niemieszczących się w binarnych opozycjach nierozstrzygalników) miała zatem na celu uwolnienie twórczej mocy samego języka, co miałoby szansę odnowić polityczną wyobraźnię ludzi.

2 Zdecydowanie bardziej klarownie te rodzaje myślenia odsyłają do opozycji 'centrum-peryferia' wówczas, gdy odwołamy się do ich anglojęzycznych nazw: student-centred pedagogy, teacher-centred pedagogy oraz curriculum-centred pedagogy. 
kontinuum pomiędzy pracą $\mathrm{w}$ odniesieniu do narzuconego $\mathrm{z}$ góry centralnego programu nauczania oraz całkowitą wolnością programową się on/a znajduje - jest wskazanie punktu wejściowego [Einstieg], czyli takiego zagadnienia, przez które można uczniów wprowadzić do całej dziedziny wiedzy, do jakiegoś wymiaru świata in extenso. Kształcenie polega zatem na skupieniu uwagi na konkretnym zagadnieniu i w tym sensie mamy do czynienia $\mathrm{z}$ koncentracją, $\mathrm{z}$ postawieniem czegoś $\mathrm{w}$ centrum uwagi. Jednakże, takie skoncentrowanie jedynie chwilowo wyłącza wszystkie inne sprawy, rzeczy, zjawiska, wymiary świata jako nieistotne, ponieważ de facto pełni funkcje wprowadzenia do tych - chwilowo wykluczonych - kwestii. Centracja w pedagogice ma zatem charakter otwierający świat, a nie marginalizujący jego różne wymiary. Świadomość post-strukturalnej krytyki kategorii centrum powinna jednak nas uczulić, że również w przypadku pedagogiki ów centryzm może przybrać formy patologiczne: naznaczające i wykluczające wszelką inność. W niniejszym artykule postaram się zasygnalizować także taką możliwość.

W istocie, w kolejnych sekcjach postaram się najpierw krótko scharakteryzować wyodrębniane w literaturze odmiany pedagogicznego centryzmu, wskazując także na możliwości ich osunięcia się w myślenie kategoriami opozycji 'centrum-peryferia'. Następnie dokonam zarysu dopiero wyłaniającej się dzisiaj formuły takiego skoncentrowania, w której na pierwszy plan w edukacji wysuwa się rzecz.

\section{Pedagogiki skoncentrowane}

Wydaje się, że spośród osi, wokół których koncentrują się różne orientacje pedagogiczne najbardziej paradoksalny charakter ma program kształcenia. Pedagogika programocentryczna (curriculum-centred pedagogy) wydaje się być powszechnie odrzucana jako przejaw alienacji edukacji i reifikacji podmiotów biorących w niej udział (por. Wood, 2004), ale jednocześnie ciągle zdaje się stanowić dominującą wśród nauczycieli orientację (por. Klus-Stańska, 2014). Jak sugeruje Wood (2004), może to wynikać z ciągłego nacisku biurokratycznego systemu organizacji i kontroli systemów oświatowych, dla którego program kształcenia jest podstawowym narzędziem wpływu na praktyki kształceniowe. Niezależnie od tego orientacja ta charakteryzuje się nastawieniem na „realizację programu”, która staje się bardziej istotna niż potrzeby uczniów, pomysły nauczycieli, realne możliwości czasowe, którymi dysponują jedni i drudzy, a także ważniejsza niż wszelkie nieprzewidziane wcześniej okoliczności, w jakich może zachodzić kształcenie. To właśnie ułożony a priori program kształcenia stanowi zewnętrznie (i w tym sensie również obiektywnie) narzucony wymóg, do którego muszą dostosować się 
wszystkie podmioty edukacyjne (por. Bourdieu i Passeron, 1990). Wymóg ten narzuca nie tylko zestaw treści, ale także tempo pracy pedagogicznej i spodziewane jej efekty (a przez to pośrednio wskazuje również na odpowiednie metody tej pracy).

Co istotne, skoncentrowanie na programie kształcenia nie oznacza skoncentrowania na treściach kształcenia, ale właśnie na ich odpowiednim wyborze, uporządkowaniu i czasowym rozplanowaniu. To program, a nie treści są w centrum takiej pedagogiki. W takim układzie nauczycielom chodzi o to, żeby „zrealizować program”, a nie o to, żeby studiować razem z uczniami jakieś zagadnienie. Pierwszeństwo ma biurokratyczny dokument i właśnie dlatego należy w tym przypadku mówić o postępującej alienacji kształcenia. Stąd w przypadku pedagogiki programocentrycznej mamy do czynienia z funkcjonowaniem opozycji 'centrum-peryferia' w sensie, który poddaje krytyce post-strukturalizm. Nie jest to zatem skoncentrowanie istotowo pedagogiczne, gdyż - jak już wspomniałem - ma to charakter otwierający daną domenę rzeczywistości, a nie marginalizujący wszystko poza centrum. Niewątpliwie, curriculum-centred pedagogy należy uznać za przypadek narzucenia praktykom edukacji zewnętrznej wobec nich logiki, a dokładniej logiki biurokratycznej rozliczalności.

Nieco innym przypadkiem jest pedagogika skoncentrowana na nauczycielu (teacher-centred pedagogy). Jest to podejście, które w literaturze dydaktycznej uznaje się za klasyczne. Wynika ono z przekonania, że nauczanie wywołuje uczenie się ucznia, w związku z czym kluczowe dla samego procesu kształcenia są „czynności nauczyciela” (por. Kruszewski, 1991). Nawet jeśli - jak to się dzieje w podręczniku Wincentego Okonia (1998) - wskazuje się na trzy zasadnicze wymiary kształcenia, oprócz czynności nauczycieli wymieniając czynności uczniów i skutki obu tych rodzajów czynności (czyli: wyniki kształcenia i wychowania) (s. 9-10), to jednak całość opisu kształcenia jest skoncentrowana na czynnościach nauczycieli, które mają otwierać świat nowemu pokoleniu. Dzieje się tak, ponieważ nauczycielowi przypisuje się funkcję kierowniczą, a o czynnościach uczniów myśli się jako o skutkach działań nauczycieli. W takim układzie wydaje się zrozumiałe, że nie należy zwracać zbyt wielkiej uwagi na czynności, które ex definitione mają charakter wtórny (tj. czynności ucznia). Krytyka takiego ukierunkowania myślenia pedagogicznego dokonuje się już od ponad wieku, czyli od czasów Nowego Wychowania, a ostatnio ma związek z dominacją myślenia konstruktywistycznego w dydaktyce (zob. Klus-Stańska, 2002). Mnogość argumentów przeciwko pedagogice skoncentrowanej na nauczycielu jest ogromna i obejmuje zarówno te natury etycznej (marginalizacja osoby ucznia, jego potrzeb 
i świata życia), ontologicznej (tworzenie pozoru rzeczywistości założeniowej), politycznej (kształcenie nowego pokolenia wduchu reaktywności i podporządkowania władzy), jak i psychologicznej (rozbieżność z przebiegiem naturalnego uczenia się i warunkami sprzyjającymi rozwojowi ontogenetycznemu), czy technicznej (niska skuteczność metod transmisyjnych).

Właśnie w opozycji do tego modelu wiek XX został przez Ellen Key (1928 [190o]) ogłoszony stuleciem dziecka. Naturalnie korzeni pedagogiki pajdocentrycznej należy szukać znacznie wcześniej - co najmniej u Jean-Jacques’a Rousseau. Sam zaś pajdocentryzm - podobnie jak orientacje pedagogiczne mające w centrum program kształcenia czy nauczyciela - jest nurtem niezwykle zróżnicowanym, a jego opis w tym artykule ma jedynie charakter zarysu. Wydaje się jednak, że warto zwrócić uwagę na dwa zasadnicze sposoby, w jakie próbuje się konceptualizować student-centred pedagogy.

Pierwszy $\mathrm{z}$ nich związany jest $\mathrm{z}$ drogą, jaką post-deweyowski rekonstrukcjonizm (zob. Męczkowska, 2002) przeszedł dzięki rewolucjom post-piagetowskiego progresywizmu, a później konstruktywizmu (Bruner, 1978; Klus-Stańska, 2002). Pedagogika skoncentrowana na uczniu w tym układzie oznacza, że pedagodzy skupiają się na procesach poznawczych, które zachodzą w umysłach uczniów podczas procesu kształcenia. Całość działań uczniów i nauczycieli koncentruje się zatem na inicjowaniu zmian w strukturach poznawczych uczniów. Oznacza to tyle, że kształcenie ma stymulować intelektualną pracę nowego pokolenia i eliminować czynności jałowe lub wprost uwsteczniające rozwój poznawczy (por. Klus-Stańska i Nowicka, 2005). Jednakże skoncentrowanie na uczniu nie eliminuje tutaj świata jako przedmiotu poznania - wręcz przeciwnie, wydaje się być jedynie drogą, przez którą kolejne domeny rzeczywistości otwierają się przed nowym pokoleniem. Dominacja tej perspektywy $\mathrm{w}$ teorii edukacji jest dzisiaj poddawana krytyce jako prowadząca do redukcji edukacji do procesu uczenia się (tzw. learnification of education, Biesta, 2006), który - w przeciwieństwie do edukacji - ma charakter stricte indywidualny i nie wymaga specjalnej aranżacji, tzn. ma charakter procesu antropologicznego (ludzie uczą się zawsze, w każdych warunkach, niezależnie od wszystkiego). Poza tym, taka redukcja edukacji do uczenia się sprzyja ekonomizacji oświaty (zob. Biesta, 2010; Simons i Masschelein, 2008), ponieważ uczenie się prowadzi do dających się uchwycić (także ilościowo) efektów, co kończy się ujmowaniem kształcenia jako ekonomicznie rozliczalnego procesu produkcji zaplanowanych z góry efektów uczenia się.

Inaczej rzecz ma się w drugim rodzaju pojmowania pajdocentryzmu, który można wywodzić z filozofii edukacji Rousseau, z tym zastrzeżeniem, że o ile u Rousseau kluczowym powodem wycofania się nauczyciela było uwolnie- 
nie wewnętrznej siły kierującej dzieckiem, tj. natury, o tyle we współczesnej wersji tego nurtu chodzi o dostosowanie edukacji do potrzeb każdego ucznia, które nie muszą mieć naturalnego czy wewnętrznego charakteru. Kluczowe okazuje się tutaj przemieszczenie nurtów bezpośrednio odwołujących się do psychologii humanistycznej (por. Rylke i Klimowicz, 1982) w obręb wpływów ideologii neoliberalizmu, redefiniującej potrzeby ucznia jako potrzeby klienta. Nacisk na dobrostan ucznia (student's well-being) jako podstawowy punkt odniesienia powoduje w takim układzie podporządkowanie wszystkich elementów kształcenia aktualnie definiowanym potrzebom konkretnego klienta. W tym sensie mówi się już wprost nie o edukacji zindywidualizowanej, ale o kształceniu spersonalizowanym - podobnie jak personalizuje się interfejs systemów operacyjnych w smartfonach albo wygląd samochodu przy zakupie (por. Laboratory..., 2018). Znów mamy tutaj zatem do czynienia $\mathrm{z}$ centryzmem $\mathrm{w}$ sensie krytykowanym przez post-strukturalizm, czyli takim, który - w tym przypadku - wyklucza wszystko, co nie jest potrzebą klienta. Wszelkie inne elementy kształcenia przestają mieć znaczenie.

Problem, przed którym stajemy wydaje się być zatem typowy dla obecnej egzystencjalnej sytuacji ludzi Zachodu. Jest to problem braku wyobraźni ideowej czy ideologicznej. Może się nam wydawać, że w zasadzie nie mamy wyboru i powinniśmy zawiesić moc argumentów krytycznych przeciwko pajdocentryzmowi. Wydają się one przekonujące, ale jeśli miałyby prowadzić do przyjęcia orientacji skoncentrowania na programie kształcenia albo na nauczycielu, to lepiej chyba po prostu nie brać ich pod uwagę. Innymi słowy, argumenty przeciwko koncentracji na programie lub nauczycielu są tak poważne, że nie sposób zwyczajnie powrócić do tych modeli. Jednakże całe to rozumowanie bazuje na założeniu, że nie ma innej możliwości konceptualnej, że funkcjonujemy w obrębie alternatywy: skoncentrowania albo na nauczycielu/programie, albo na uczniu. Założenie to okazuje się jednak fałszywe.

\section{Pedagogika skupiona na rzeczy}

Inaczej niż w tradycji polskiej, klasyczna dydaktyka niemiecka systematycznie odwołuje się do pojęcia trójkąta dydaktycznego, który wskazuje na trzy zasadnicze wymiary każdej sytuacji dydaktycznej: ucznia, nauczyciela i rzeczy (Bönsch, 2006). Właśnie ta koncepcja wydaje się sugerować, że istnieje inna możliwość niż skoncentrowanie pedagogiki na nauczycielu, uczniu, czy też biurokratycznym dokumencie narzucającym dane treści kształcenia i ich uporządkowanie. Wydaje się, że zapomnieliśmy o roli rzeczy w kształceniu o roli, która jest zupełnie fundamentalna. Podejmując się poniżej opisu pedagogiki skupionej na rzeczy (thing-centred pedagogy) dokonam rekonstrukcji 
czterech głównych założeń, które jej towarzyszą: 1) jesteśmy mieszkańcami jednego, wspólnego świata, 2) rzecz jest pierwotna wobec przedmiotu, 3) rzeczy nie można używać, a jedynie można ją studiować dla niej samej (rzecz jest istotowo bezużyteczna), 4) istnieje edukacyjna równość, której miarą jest rzecz (edukacja nie istnieje bez równości ludzi wobec rzeczy).

\section{Jeden świat}

Od czasu wprowadzenia przez Edmunda Husserla (2017 [1936]) pojęcia świata życia do humanistyki, stało się ono kluczowe dla współczesnej socjologii i teorii polityki (zob. Schütz, 2008; Habermas, 1999, 2002)3. Stąd dominujące stało się założenie, które zwykliśmy przyjmować niejako a priori, że ludzie żyją w różnych światach, przez pryzmat których interpretują zdarzenia, sytuacje i działania innych ludzi. Tymczasem, o ile w sensie psychologicznym czy socjologicznym możemy rzeczywiście mówić o różnych światach (społecznych czy mentalnych), o tyle - jak wykazała Arendt (2011) - w sensie ontologicznym dla istnienia edukacji niezbędne jest przyjęcie założenia, według którego wszyscy jesteśmy mieszkańcami jednego, wspólnego świata. W świecie tym „zawsze żyją pospołu ludzie w różnym wieku” (s. 220), jest on zatem przestrzenią otwartą dla wielości różnorodnych ludzi ${ }^{4}$. Edukacja dla Arendt ma charakter ontologicznej konieczności ze względu na fakt nieustannego przybywania na świat nowych ludzi (natality) do starego świata. Nowo narodzony człowiek pojawia się zatem w świecie, „który był przed nim, który będzie trwał nadal po jego śmierci i w którym ma ono spędzić całe życie" (s. 224). Edukacja wiąże się zatem ze zderzeniem starego świata i nowo narodzonego przybysza5. Zderzenie to wymaga działania, które ma dwukierunkowy charakter:

dziecko wymaga szczególnej ochrony i troski, aby nie spotkało go nic złego ze strony świata. Ale także świat potrzebuje ochrony przed niszczącym naporem nowych przybyszy, którzy uderzają weń wraz z każdym nowym pokoleniem (s. 225).

3 Naturalnie zakres oddziaływań tej koncepcji jest daleko większy niż te dwie wymienione dziedziny wiedzy. Oprócz fundamentalnej roli, jaką odgrywa to pojęcie we współczesnej pedagogice, warto tu jeszcze wspomnieć o znaczeniu, jakie miało ono dla rozwoju tak zwanego zwrotu anty-psychiatrycznego (zob. Laing, 1995).

4 Por. słynną tezę Arendt (2000, s. 11), wedle której to „ludzie, a nie Człowiek, żyją na Ziemi i zamieszkują świat”.

5 „Gdyby dziecko nie było w tym ludzkim świecie przybyszem, lecz po prostu nieukształtowanym jeszcze żywym stworzeniem, edukacja byłaby tylko funkcją życia i polegałaby jedynie na trosce o podtrzymanie istnienia i takiemu przygotowaniu, które wszystkie zwierzęta zapewniają swemu potomstwu" (Arendt, 2011, s. 224). 
Edukacja polega zatem na tym, że istniejące pokolenie wprowadza nową generację do starego, wspólnego świata, który w swoich czasowych horyzontach przekracza zarówno dorosłych, jak i młodych (istniał już przed nimi, i będzie istnieć po ich śmierci). Bez założenia istnienia jednego, wspólnego świata sam koncept edukacji nie ma zatem sensu. Kluczowe jest tutaj jednak to, w jaki sposób nowi przybysze (newcomers) i stary świat są od siebie zależni. Nowe pokolenie nie ma innego świata niż stary. Młodzi będą musieli spędzić tutaj całe swoje życie. Tymczasem ów stary świat

\begin{abstract}
jako dzieło śmiertelników, niszczeje, a ponieważ nieustannie zmienia mieszkańców, ponosi ryzyko, że stanie się równie śmiertelny jak oni. Aby chronić świat przed śmiertelnością jego twórców i mieszkańców, należy go ciągle odnawiać. (...) Nasza nadzieja spoczywa zawsze w nowym, które przynosi ze sobą nowe pokolenie (s. 232).
\end{abstract}

Właśnie dlatego, z jednej strony, podkreśla Arendt, nie wolno dyktować młodym, jacy mają oni być i jaka ma być ich przyszłość i przyszłość świata - nie wolno niweczyć ich nowości. Projekty pokolenia dorosłych nie mają mocy odnawiania, bowiem należą już do starego świata. To młodzi muszą sami wejść w relację ze starym światem i odnowić go według własnego pomysłu. Z drugiej jednak strony oznacza to, że edukacja musi być istotowo konserwatywna, w tym sensie, że musi wprowadzać młodych do starego świata, a nie do nieistniejącego, utopijnego świata wymarzonego przez dorosłych. Edukacja nie jest projektowaniem przyszłości ludzi i świata, ale jej uwalnianiem, oddawaniem jej młodym i ich inwencji.

Wszystkie tropy wprowadzone przez Arendt są nieodzowne w myśleniu o pedagogice skupionej na rzeczy. Jest jeden wspólny świat, do którego nieustannie przybywają jego nowi mieszkańcy. Nie ma innego wyjścia, jak tylko wprowadzić ich w ów stary świat, który jedynie za pośrednictwem mocy ich nowości może zostać odnowiony i dzięki temu może trwać dalej, goszcząc kolejne pokolenia. Oczywiście kluczowe pytanie dotyczy tego, czym jest ów świat, z czego się składa i na czym polega wprowadzanie do świata w taki sposób, dzięki któremu może on zostać odnowiony przez nowe pokolenie. Odpowiedzi udziela pedagogika skupiona na rzeczy, powiadając, że świat jest światem rzeczy. Chcąc uczynić tę tezę jaśniejszą należy teraz zwrócić się do Heideggera.

\title{
Przedmiot i rzecz
}

Dla Heideggera przedmiot jest pojęciem wtórnym i powstaje za sprawą redukcji rzeczy do jej poręcznego, funkcjonalnego wymiaru jako czegoś 
użytecznego. Przedmiot jest zatem pojmowany jako zasób dostawiony do Ze-stawu [Ge-stell] (Heidegger, 1977, 2002a) i jako taki odpowiada istocie techniki, którą Heidegger odsłania w swoim krytycznym badaniu. W tym sensie, ponieważ „[p]rzedmiot jest jednością stałości zasobu” (2002b, s. 66), myślenie w kategoriach przedmiotów i ich funkcji jest typowe dla metafizyki jako zachodniego sposobu bycia (zob. Michalski, 1978, s. 210). Inaczej rzecz biorąc, przedmiot jest - wedle Heideggera - projekcją podmiotu. Jest nałożeniem potrzeb i wyobrażeń subiectum na rzecz, która ulega funkcjonalizującej redukcji, stając się obiektem przeznaczonym do rozporządzania i zużywania w zaspokajaniu potrzeb podmiotu. Przedmiot jest tym, co podmiot włącza w swoje kalkulacje, co jest elementem jego codziennej krzątaniny (por. Heidegger, 2004), czym się dysponuje w oparciu o posiadaną wiedzę, na czym się można „znać” i w czego używaniu można być „dobrym”.

Rzecz natomiast nieustannie wymyka się naszemu poznaniu. Obcowanie $\mathrm{z}$ rzeczą polega na dwukierunkowym ruchu pociągającego nas wymykania się, które Heidegger zwie myśleniem:

To, co się nam wymyka, pociąga nas przy tym, czy zauważamy to natychmiast, czy w ogóle nie zauważamy. Kiedy dostaniemy się w ciąg wymykania się, ciągniemy (...) ku temu, co nas przyciąga - wymykając się (2000, s. 15).

Rzecz jest zatem źródłem pytań jako to, co daje do myślenia (s. 11), czyli to, co najbardziej poważne [das Bedenklichste] (s. 20). Dzieje się tak, ponieważ rzecz skupia ${ }^{6} \mathrm{w}$ sobie wszystkie wymiary światowości świata, które Heidegger w swoich późnych tekstach nazywa czwórnią:

Jak istoczy rzecz? Rzecz rzeczy (dingt). Rzeczenie (Dingen) skupia. Skupia ono, wydarzając czwórnię, jej pobyt, w coś zawsze pobytowego: w tę, w tamtą rzecz (2002C, s. 153).

Rzecz uderza nas swoją złożonością, która - chociaż ciągle się nam wymyka - jest „bliżeniem świata” (s. 160). Dlatego relacja człowieka z rzeczą nie polega na rozporządzaniu, obrabianiu i zużywaniu, ale na podążaniu za jej ruchem wymykania się, eksplorowaniu jej, na jej studiowaniu?

6 Heidegger (2002c) używa słowa Versammlung, które Janusz Mizera znacząco przekłada w różnych fragmentach tekstu bądź to jako skupianie, bądź to jako zbieranie. Ze względów na objętość tego tekstu pomijam tutaj to drugie - co najmniej równie fundamentalne - znaczenie.

7 W tym sensie Heidegger (200o, s. 12) pisze o źródłowym sensie zainteresowania i interesu, który wypływa z łacińskiego inter esse, bycia między rzeczami. 
Warto odwołać się w tym miejscu do pojęcia instauracji, które wprowadza Etienne Sourieau (1943, za: Latour, 2011). Dotyczy ono zjawiska bycia kierowanym przez dzieło, o którym powszechnie mówią twórcy. Z jednej strony wydaje się, że artysta jest twórcą swojego dzieła, ale z drugiej - dzieło zaskakuje swojego autora, który, umożliwiając pojawienie się czegoś niezaprojektowanego i niespodziewanego dla siebie, sam okazuje się jedynie narzędziem swego dzieła. W świetle pojęcia instauracji można zatem powiedzieć, że rzecz nie jest inkorporacją jakichś ludzkich idei, ale ma ona swoją wewnętrzną, niezależną od poznającego i tworzącego podmiotu logikę, śladem której - wszakże - można podążać. Jej ujawnienie i uobecnienie jest dla Sourieau zadaniem dzieła sztuki. Podążanie za tą logiką jest natomiast studiowaniem rzeczy.

\section{Studiowanie}

Jak twierdzą Jan Masschelein i Maatren Simons (2013), podstawowym zadaniem nauczyciela jest położenie rzeczy na stole ${ }^{8}$. Ten gest bowiem skupia uwagę wszystkich obecnych w sali na tej rzeczy, a jednocześnie udostępnia ową rzecz dla wszystkich zebranych w ten sposób wokół rzeczy. Kładzenie rzeczy na stole ma jednak jeszcze jeden fundamentalny sens. Kładąc na stole przedmiot zawieszamy jego funkcjonalne powiązania, abstrahujemy od jego codziennego użytku i próbujemy studiować go dla niego samego. Inaczej rzecz biorąc - czynimy go na powrót rzeczą. Silnik spalinowy w klasie szkolnej nie jest rozpatrywany ze względu na swoją cenę, wydajność, czy kompatybilność $\mathrm{z}$ różnymi typami pojazdów - jest on rozbierany na części i składany z powrotem w całość tylko po to, żeby poznać jego budowę (s. 37). Podobnie trójkąt narysowany na tablicy nie jest zarysem działki, której pole należy obliczyć, aby oszacować jej rynkową wartość - jest on wyłącznie i po prostu trójkątem, którego własności staramy się zrozumieć dla nich samych.

Zawieszenie zestalonych funkcjonalnych powiązań danego przedmiotu, jego urzeczowienie powoduje, że dwie sprawy - o których pisała wspomniana wcześniej Arendt - stają się możliwe. Po pierwsze, uczniowie/studenci mają szansę na ustanowienie relacji z daną częścią świata, tj. z daną rzeczą. Naturalnie są oni już „od dawna” zanurzeni w sieci funkcjonalnych powiązań $\mathrm{z}$ oraz między przedmiotami. Jednakże dopiero zawieszenie tych odniesień powoduje, że możliwe jest ustanowienie relacji konkretnego młodego człowieka z daną częścią świata. Młodzi zostają bowiem postawieni przed

8 Przy czym, naturalnie, „stół” ma tutaj więcej niż jedno znaczenie - także to, które wskazuje na powiązanie „tablicy” i „stołu” (la table). 
zadaniem podjęcia jakiejś decyzji w sprawie tej relacji, a sama rzecz zostaje wyodrębniona z sieci codziennie obowiązujących powiązań i staje przed młodymi jako taka. Po drugie, urzeczowienie przedmiotu ma również charakter semantyczny, to znaczy stawia pod znakiem zapytania znaczenie danej rzeczy. Zawieszenie funkcjonalnych powiązań przedmiotu powoduje, że nie wiadomo już, „do czego to służy” ani „co to jest”. Oznacza to możliwość odnowienia znaczenia tej rzeczy albo - jak za Agambenem (2006) proponują Masschelein i Simons (2013) - możliwość jej profanacji, czyli otwarcia na nowe użycia. Odwołując się do terminologii Arendt należałoby zatem powiedzieć, że urzeczowienie przedmiotu otwiera drogę do wprowadzenia młodych do starego świata w taki sposób, który daje szansę na jego odnowienie.

Co niezmiernie istotne, podążanie za wewnętrzną logiką rzeczy jest związane z nieustępliwym wysiłkiem, który - paradoksalnie - ma istotowo bezproduktywny charakter. Studiowanie można bowiem określić jako znój powtarzania: powtórnej lektury, ponawianej obserwacji, ciągłego eksperymentowania i ćwiczenia. W tym sensie powtarzanie jawi się jako zasadnicza pedagogiczna praktyka, której jałowość czy zacofanie można zarzucać tylko z perspektywy zekonomizowanego pojmowania kształcenia jako nabywania funkcjonalnych własności przez podmiot (Vlieghe, 2013). Jednak pomimo wpisanego weń wysiłku, studiowanie nie jawi się jako praca, a przymus z nim związany nie ma charakteru zewnętrznie motywowanego obowiązku, ale jest nieomalże fizjologiczną koniecznością podążania za rzeczą. To rzecz nas pociąga - oddalając się.

Kluczowe okazuje się tutaj badanie Tysona Lewisa (2015), który w swoim fundamentalnym dziele $O$ studiowaniu rozwinął ideę studiowania w odniesieniu do pojęcia czystej potencjalności Agambena (1999). Agamben powiada, że potencjalność można konceptualizować z perspektywy aktu, czyli docelowej bądź przypadkowej realizacji danego potencjału - wówczas jednak o potencjalności myślimy w sposób zapośredniczony (wyznaczony przez akt). Tymczasem można myśleć o czystej potencjalności wówczas, gdy istotowo nie ulega ona aktualizacji, gdy nie prowadzi do jakichkolwiek rezultatów, ale po prostu jest. W ten sposób - dla przykładu - poeta, który nie pisze wierszy jest czystą potencjalnością poezji. Lewis (2015) twierdzi, że studiowania nie można uchwycić bez odwołania się do pojęcia czystej potencjalności. Studiowanie nie kończy się bowiem jakimś rezultatem, ale raczej może zostać przerwane po to, ażeby zająć się inną, typowo produktywną praktyką (jak na przykład teoretyzowaniem, czy po prostu pisaniem). Natomiast, o ile się studiuje, o tyle podąża się za rzeczą, która nieustannie się wymyka. Dlatego jeśli opisuje się studiowanie per se, to nie prowadzi ono do jakichkolwiek rezultatów - jest 
całkowicie bezproduktywnym podążaniem za rzeczą dla niej samej. Właśnie dlatego - zauważa Lewis - studiowanie jest dzisiaj jednym z najsilniej zmarginalizowanych $\mathrm{z}$ wszelkich skolonizowanych pojęć pedagogicznych. Jego biurokratyczny sens ( $t j$. uczęszczanie na zajęcia w ramach edukacji wyższej), który dominuje w dyskursie publicznym, jest prostym zaprzeczeniem sensu samej praktyki studiowania (bezproduktywnego podążania za rzeczą) i doświadczenia, które się z tym wiąże.

\section{Równość}

Położenie rzeczy na stole powoduje, że studiowanie rzeczy ma charakter publiczny (Masschelein i Simons, 2013). Rzecz jest na stole dla wszystkich i wszyscy mogą ją badać, przyglądać się jej, manipulować nią, eksperymentować z nią itp. To, co nauczyciel mówi o rzeczy może być (i jest) natychmiast konfrontowane $\mathrm{z}$ samą rzeczą. $\mathrm{W}$ tym sensie należy mówić o autorytecie rzeczy (Vlieghe i Zamojski, 2019). Wszelkie powstające w klasie hipotezy dotyczące natury rzeczy są konfrontowane z nią samą. To rzecz, do której wszyscy mogą się odwołać, decyduje o tym, które hipotezy, argumenty, stanowiska formułowane w stosunku do rzeczy okażą się przekonujące, a które nie. W tym właśnie sensie rzecz czyni wszystkich zebranych wokół niej studentami.

Edukacja stricto sensu nie jest możliwa bez takiej równości ludzi wobec rzeczy. Podległość dzieci autorytetowi dorosłych lub autorytetowi grupy rówieśniczej deformuje - jak zauważa Arendt (2011, s. 219-220) - edukację jako indoktrynację, która wówczas nie daje szansy młodym na wprowadzanie nowych początków do starego świata. W edukacji autorytet dorosłych i autorytet grupy rówieśniczej są zawieszone przez autorytet rzeczy, która czyni studentami wszystkich zebranych wokół niej i skupionych na podążaniu za jej wewnętrzną logiką bez względu na wiek, płeć, rodzaj, pozycję w grupie, pochodzenie, status społeczno-ekonomiczny i wszelkie inne społeczne systemy referencyjne, w odniesieniu do których zwykliśmy konceptualizować równość społeczną, ekonomiczną i polityczną (Vlieghe i Zamojski, 2019).

Bez wątpienia mamy tutaj do czynienia $z$ równością swoistą dla edukacji, która różni się od równości praw i równości szans życiowych. Nie znaczy to jednak, że równość ta - a właściwie doświadczenie tej równości - nie ma politycznego znaczenia. Nie jest to jednak równość w sensie politycznym.

Nieco światła na charakter tej edukacyjnej równości wobec rzeczy rzuca odkrycie dokonane przez Rancière’a (1991). Zauważa on, że zazwyczaj myślimy o równości (zarówno w polityce, jak i w edukacji) jako o stanie pożądanym, do którego należy się systematycznie przybliżać. Równość jest 
zatem - w takim rozumieniu - celem działania (politycznego/edukacyjnego), ale jako taka - hic et nunc równość nie istnieje. Przekonanie to jest zresztą systematycznie potwierdzane przez wszelkie demaskatorskie, krytyczne badania, które ujawniają nierówności zwłaszcza tam, gdzie myśleliśmy, że już osiągnęliśmy równość. Niemniej jednak - przekonuje Rancière - przekonanie to jest błędne.

W opozycji do takiego rozumienia równości Rancière (1991) zwraca się do postaci XIX-wiecznego nauczyciela i teoretyka edukacji, Josepha Jacotot i jego „intelektualnej przygody”. Uchodząc z Francji w okresie restauracji Burbonów, Jacotot znajduje się we Flandrii, gdzie w Leuven dostaje posadę nauczyciela języka francuskiego. On sam jednak nie zna zupełnie języka holenderskiego, którym posługują się jego uczniowie, nieznający zupełnie francuskiego. Jacotot wpada na genialny pomysł, zdobywa kilkanaście egzemplarzy dwujęzycznego wydania pewnej francuskiej powieści i - za pośrednictwem tłumacza - poleca swoim uczniom czytać książkę w znanym sobie języku holenderskim i równolegle studiować stronę tego samego tekstu zapisaną w języku francuskim. Uczniowie mają przyglądać się, szukać prawidłowości, domyślać się, co oznaczają poszczególne wyrazy, szukać reguł zapisu, łączenia znaków i wyrazów ze sobą itp. Swoją rolę Jacotot ograniczył wyłącznie do dyscyplinowania uczniów w studiowaniu tekstu oraz pomocy w opanowywaniu wymowy. Po kilku miesiącach okazało się, że mógł się już zupełnie swobodnie porozumiewać w mowie i w piśmie ze swoimi uczniami po francusku.

Rancière, opisując dydaktyczny pomysł Jacotot, zwraca uwagę na szczególną rolę książki: „wspólnej rzeczy, umieszczonej pomiędzy dwoma umysłami [która] jest miernikiem i wskaźnikiem (gauge) równości na dwa różne sposoby. [Po pierwsze jako] pomost komunikacji pomiędzy dwoma umysłami [a po drugie] jako materialne źródło weryfikacji [formułowanych sądów]" (1991, s. 32). Książka czyni wszystkich w klasie Jacotot równymi, ponieważ każdy może ją studiować i sądzić w odniesieniu do niej. Rancière pisze w związku z tym o demokracji książki (s. 38). Książka nikogo nie wyróżnia, jest dla wszystkich, po równo. Co więcej, położenie jej na stole jest gestem, który zakłada, że każdy może ją studiować: że każdy jest inteligentny. „Książka jest równością inteligencji” - powiada Rancière (kursywa $\mathrm{w}$ oryginale). $\mathrm{W}$ tym sensie równość nie jest założonym i pożądanym efektem naszego działania, ale jest założeniem, z którym przystępujemy do działania. Założeniem lub aksjomatem, który w działaniu (pedagogicznym lub politycznym) czynimy prawdą (np. s. 137). W przypadku działania edukacyjnego to rzecz położona na stole (np. książka) zrównuje ludzi i powoduje, że działają oni zgodnie z założeniem równości. Prawdopodobnie to właśnie 
doświadczenie równości w edukacji jest podstawą dla weryfikacji równości w działaniach politycznych (Vlieghe i Zamojski, 2019). Bowiem pomimo tego, że wiemy coraz więcej o tym, dlaczego równość nie jest możliwa, to jednocześnie - o ile studiowaliśmy (w przyjętym powyżej sensie) - o tyle mamy w swoich biografiach źródłowe doświadczenia bycia równym wobec rzeczy.

\section{Konkluzja}

W niniejszym artykule próbowałem wprowadzić polskiego czytelnika do wyłaniającej się w chwili obecnej nowej koncepcji orientującej pedagogikę na rzecz. Próbowałem wykazać, że skoncentrowanie pedagogiki na danym elemencie nie musi wikłać się w post-strukturalną krytykę opozycji pomiędzy centrum i peryferiami, a następnie próbowałem wyodrębnić pedagogikę skupioną na rzeczy od innych orientacji centrujących pedagogikę wokół programu kształcenia, nauczyciela i jego czynności, oraz potrzeb ucznia. Pedagogika skupiona na rzeczy, która została opisana w odniesieniu do swoich czterech podstawowych założeń, jest z pewnością nurtem bardziej złożonym niż dało się to zaprezentować w ramach tego artykułu. Poza tym jest to nurt dopiero rozwijający się, co powoduje, że argumenty krytyczne wobec takiego sposobu myślenia nie zostały jeszcze rozpoznane. Niniejszy artykuł jest zatem zupełnie wstępnym i jeszcze nie krytycznym wprowadzeniem do pedagogiki skupionej na rzeczy.

Niemniej powstaje pytanie, czy zarysowane powyżej stanowisko teoretyczne jest istotne dla różnorodnych praktyk edukacyjnych? Niewątpliwie, jak pokazałem to w innym miejscu (Zamojski, 2015), nie jest to teoria typu technicznego, która praktykom dostarcza (skutecznych) narzędzi do zastosowania w działaniu pedagogicznym. Nie jest to również teoria typu krytycznego, która dostarcza praktykom narzędzi umożliwiających podjęcie refleksji nad własną praktyką, dostrzeżenia jej złożoności i etycznych wyzwań, które są weń wpisane. Jest to raczej teoria typu po-krytycznego, która tworzy myślowy horyzont praktyk edukacyjnych, racjonalność pedagogicznego działania. W odniesieniu do słynnego rozróżnienia Klausa Mollenhauera (1986) można zatem powiedzieć, że pedagogika skupiona na rzeczy jest próbą pedagogicznej hermeneutyki (a nie hermeneutycznej pedagogiki) (zob. Hodgson i in., 2017). Jest zatem próbą wytworzenia racjonalności, w której praktycy mogą myśleć o swojej praktyce, horyzontu, w którym mogą projektować i rozumieć swoje działania, czy też - w nawiązaniu do Rancière’a - aksjomatów, zgodnie z którymi się działa, czyniąc je prawdą. 


\section{BIBLIOGR AFIA}

Agamben, G. (1999). Potentialities. Collected essays in philosophy. Przeł. D. Heller-Roazen, Stanford: Stanford University Press.

Agamben, G. (2006). Profanacje. Przeł. M. Kwaterko. Warszawa: PIW.

Arendt, H. (200o). Kondycja ludzka. Przeł. A. Łagodzka. Warszawa: Fundacja Aletheia.

Arendt, H. (2011). Kryzys edukacji. W: eadem, Między czasem minionym a przyszłym. Osiem ćwiczeń z myśli politycznej. Przeł. M. Godyń, W. Madej, Warszawa: Wydawnictwo Aletheia.

Bhabha, H. (2010). Miejsca kultury. Przeł. T. Dobragaszcz, Kraków: Wydawnictwo Uniwersytetu Jagiellońskiego.

Biesta, G.J.J. (2006). Beyond Learning: Democratic Education for a Human Future. Boulder (CO): Paradigm.

Biesta, G.J.J. (2010). Good Education in an Age of Measurement. Ethics, Politics, Democracy. Boulder-London: Paradigm Pub.

Bourdieu, P., Passeron, J.-C. (1990). Reprodukcja: element teorii systemu nauczania. Przeł. E. Neyman, Warszawa: PWN.

Bönsch, M. (2006). Allgemeine Didaktik. Stuttgart: Verlag W. Kohlhammer.

Bruner, J. (1978). Poza dostarczone informacje. Studia z psychologii poznawania. Przeł. B. Mroziak, Warszawa: PIW.

Derrida, J. (1999). O gramatologii. Przeł. B. Banasiak, Warszawa: Wydawnictwo KR.

Derrida, J. (2002). Marginesy filozofii. Przeł. A. Dziadek, J. Margański, P. Pieniążek, Warszawa: Wydawnictwo KR.

Derrida, J. (2004). Pismo i różnica. Przeł. K. Kłosiński, Warszawa: Wydawnictwo KR.

Habermas, J. (1999 - t. 1) (2002 - t. 2). Teoria działania komunikacyjnego. Przeł. A.M. Kaniowski, Warszawa: PWN.

Heidegger, M. (1977). Nauka i namysł. Przeł. M.J. Siemek. W: M. Heidegger, Budować, myśleć, mieszkać. Warszawa: Czytelnik.

Heidegger, M. (200o). Co zwie się myśleniem? Przeł. J. Mizera, Warszawa: PWN.

Heidegger, M. (2002a). Pytanie o technikę. Przeł. J. Mizera. W: M. Heidegger, Technika i zwrot. Kraków: Wydawnictwo Baran i Suszczyński.

Heidegger, M. (2002b). Przezwyciężenie metafizyki. Przeł. J. Mizera. W: M. Heidegger, Odczyty i rozprawy. Kraków: Wydawnictwo Baran i Suszczyński.

Heidegger, M. (2002c). Rzecz. Przeł. J. Mizera. W: M. Heidegger, Odczyty i rozprawy. Kraków: Wydawnictwo Baran i Suszczyński.

Heidegger, M. (2004). Bycie i czas. Przeł. B. Baran, Warszawa: PWN.

Hodgson, N., Vlieghe, J. and Zamojski, P. (2017). Manifesto for a Post-critical Pedagogy. New York - Santa Barbara (Earth, Milky Way): Punctum Books.

Hodgson, N., Vlieghe, J., \& Zamojski, P. (2018). Education and the Love for the World: articulating a post-critical educational philosophy. Foro de Educación, 16 (24), 7-20, DOI: http://dx.doi.org/10.14516/fde.576.

Husserl, E. (2017 [1936]). Kryzys nauk europejskich i fenomenologia transcendentalna. Przeł. S. Walczewska, Kraków: vis-à-vis/etiuda.

Key, E. (1928 [1900]). Stulecie dziecka. Przeł. I. Moszczeńska, Warszawa: Nasza Księgarnia.

Klus-Stańska, D. (red.) (2014). (Anty)edukacja wczesnoszkolna. Kraków: Impuls.

Klus-Stańska, D. (2002). Konstruowanie wiedzy w szkole. Olsztyn: Wydawnictwo Uniwersytetu Warmińsko-Mazurskiego.

Klus-Stańska, D., Nowicka, M. (2005). Sensy i bezsensy edukacji wczesnoszkolnej. Warszawa: WSiP.

Kruszewski, K. (red.) (1991). Sztuka nauczania - czynności nauczyciela. Warszawa: PWN. 
Kwaśnica, R. (1991). O dwóch wersjach pytania o przedrozumienie. Do pedagogiki naukowej i pedagogów z marginesu. W: J. Rutkowiak (red.), Pytanie - dialog - wychowanie. Warszawa: PWN.

Laboratory for Education and Society (2018). Sketching a Place for Education in Times of Learning. Dordrecht - Leuven: Springer.

Laing, R.D. (1995). Podzielone „Ja”. Egzystencjalne studium zdrowia i choroby psychicznej. Przeł. M. Karpiński, Poznań: Dom Wydawniczy REBIS.

Latour, B. (2011). Reflections on Etienne Sourieau's 'Les diffèrents modes d'existence'. Przeł. St. Muecke. W: L. Bryant, N. Srnicek, G. Harman (red.), The Speculative Turn: Continental Materialism and Realism. Melbourne: re.press.

Lévinas, E. (2000). Inaczej niż być lub ponad istotą. Przeł. P. Mrówczyński, Warszawa: Wydawnictwo Aletheia.

Lewis, T. (2015). On Study: Giorgio Agamben and Educational Potentiality. London: Routledge.

Masschelein, J., Simons, M. (2013). In Defence of the School. A Public Issue. E-ducation Culture \& Society Pub.: Leuven.

Męczkowska, A. (2002). Od świadomości nauczyciela do konstrukcji świata społecznego. Nauczycielskie koncepcje wymagań dydaktycznych a problem rekonstrukcyjnej kompetencji uczniów. Kraków: Impuls.

Michalski, K. (1978). Heidegger i filozofia współczesna. Warszawa: PIW.

Mollenhauer, K. (1986). Umwege. Über Bildung, Kunst und Interaktion. München: Juventa.

Rancière, J. (1991). The Ignorant Schoolmaster (Kristin Ross, Trans.). Stanford (CA): Stanford University Press.

Rylke, H., Klimowicz, G. (1982). Szkoła dla ucznia. Jak uczyć życia z ludźmi? Warszawa: WSiP.

Said, E.W. (1991). Orientalizm. Przeł. W. Kalinowski, Warszawa: Państwowy Instytut Wydawniczy

Schütz, A. (2008). O wielości światów. Szkice z socjologii fenomenologicznej. Przeł. B. Jabłońska, Kraków: Zakład Wydawniczy NOMOS.

Simons, M., Masschelein, J. (2008). The Governmentalization of Learning and the Assemblage of a Learning Apparatus. Educational Theory, 58 (4), 391-415.

Sourieau, E. (1943). Les diffèrents modes d'existence. Paris: Presses Universitaires de France.

Szkudlarek, T. (1993). Postkolonializm jako dyskurs tożsamości: w stronę implikacji dla polskich dyskusji edukacyjnych. W: Z. Kwieciński, L. Witkowski (red.), Spory o edukację. Warszawa: Instytut Badań Edukacyjnych.

Szkudlarek, T. (red.) (1995a). Różnica, tożsamość, edukacja. Szkice z pogranicza... Kraków: Impuls.

Szkudlarek, T. (1995b). Dialektyka Innego i postkolonialna tożsamość. W: M. Urlińska (red.), Edukacja a tożsamość etniczna. Toruń: Wydawnictwo Naukowe UMK.

Szkudlarek, T. (1997). Poststrukturalizm a metodologia pedagogiki. AUNC XIII Socjologia Wychowania, 317.

Vlieghe, J. (2013). Experiencing (im)potentiality: Bollnow and Agamben on the educational meaning of school practices. Studies in Philosophy and Education, 32 (2), 189-203.

Vlieghe, J. (2016). Edukacja w warunkach szkolnych. Ku pedagogice skupionej na rzeczy. Przeł. P. Zamojski. Studia i Badania Naukowe. Pedagogika, X (1), 15-33.

Vlieghe, J., Zamojski, P. (2019). Towards an Ontology of Teaching. Thing-centred pedagogy, affirmation, and love for the world. Cham: Springer.

Wagenschein, M. (2010). 'Teaching to Understand: On the Concept of the Exemplary in Teaching'. W: I. Westbury, S. Hopmann, i K. Riquarts (red.), Teaching as a Reflective Practice: The German Didaktik Tradition, (s. 161-175). Mahwah-London: Lawrence Erlbaum Associates Publishers. 
Wood, E. (2004). A new paradigm war? The impact of national curriculum policies on early childhood teachers' thinking and classroom practice. Teaching and Teacher Education, 20, (4), 361-374.

Young, R.J.C. (2004). White Mythologies. Writing History and the West. London - New York: Routledge.

Zamojski, P. (2015). Philosophy for Education - an attempt at exercise in thought. Kwartalnik Pedagogiczny, 1 (235), 127-151.

\begin{abstract}
Thing-centred Pedagogy: an Introduction

In this article I aim to outline the concept of thing-centred pedagogy. I begin with the analysis of diverse forms of pedagogy focusing on the curriculum, teachers, and students. This leads me to the well-known problem of decay of our ideological imagination: it seems that in the face of serious allegations against curriculum-centred and teacher-centred pedagogies we are unable to perceive education otherwise than as student-centred, regardless of some significant problems with such an approach. Finally, thing-centred pedagogy is outlined as a propositional way out of this deadlock. The analysis consists of four basic assumptions of thing-centred pedagogy: that there is one common world, that a thing exists prior to an object, that one cannot use things but can study them, and that there is educational equality enabled by a common thing of study.
\end{abstract}

KEYWORDS: Arendt, post-critical pedagogy, thing-centred pedagogy, studying, a thing 